Article

\title{
Environmentally benign and economic synthesis of covalent triazine-based frameworks
}

\author{
Ling Zhang a,b, Xue Liu b, Rui-Xia Yang b, Nian-Yu Huang a, Wei-Qiao Deng b,* \\ a Hubei Key Laboratory of Natural Products Research and Development, College of Biological and Pharmaceutical Sciences, China Three Gorges \\ University, Yichang 443002, Hubei, China \\ b State Key Laboratory of Molecular Reaction Dynamics, Dalian Institute of Chemical Physics, Chinese Academy of Sciences, Dalian 116023, Liaoning, \\ China
}

\section{A R T I C L E I N F}

\section{Article history:}

Received 30 November 2016

Accepted 25 December 2016

Published 5 March 2017

\section{Keywords:}

Covalent triazine-based framework

Aryl bromide

Cyanation

Potassium hexacyanoferrate(II)

Palladium acetate

\begin{abstract}
A B S T R A C T
Covalent triazine-based frameworks (CTFs) are important microporous materials with a wide range of applications. Here, we demonstrate an environmentally benign and economic synthetic pathway to CTFs. The monomers used for CTFs, aromatic nitriles, were obtained by cyanation using nontoxic potassium hexacyanoferrate(II) in place of commonly used toxic cyanides. Then, the CTFs were synthesized by trimerization of the corresponding cyano monomers in molten zinc chloride. A series of CTFs was synthesized, and the highest Brunauer-Emmett-Teller surface area measured in this series was $2404 \mathrm{~m}^{2} / \mathrm{g}$. Among the synthesized CTFs, $\mathrm{CTF}_{\mathrm{DCP}}$ exhibited excellent $\mathrm{CO}_{2}$ adsorption properties, with a $\mathrm{CO}_{2}$ uptake of $225 \mathrm{mg} / \mathrm{g}$ at $0{ }^{\circ} \mathrm{C}$.
\end{abstract}

(C) 2017, Dalian Institute of Chemical Physics, Chinese Academy of Sciences. Published by Elsevier B.V. All rights reserved.

\section{Introduction}

The field of microporous materials has recently seen remarkable development owing to the potential applications of these materials in gas storage, separation and catalysis [1-4]. Compared with traditional porous materials, organic microporous materials have the advantages of high specific surface areas, good solubility, diverse synthetic methods and wide applicability [2]. With the ever increasing sophistication of synthetic methods available for the construction of organic porous materials, porous materials with various functions can now be synthesized according to researchers' diverse needs.

Covalent organic frameworks (COFs) are a unique class of crystalline porous organic polymers with inherent porosity and periodic molecular ordering [5-7]. It is, however, difficult to construct crystalline COFs because their syntheses require reversible condensation reactions that have to be carried out under thermodynamic rather than kinetic control [8].

Covalent triazine-based frameworks (CTFs) are a special and emerging class of COFs [9] that are produced by ionothermal trimerization of aromatic polynitriles in molten $\mathrm{ZnCl}_{2}$ to give triazine rings [10]. For example, the first reported CTF, CTF-1 [10], was prepared by trimerization of $p$-dicyanobenzene. CTFs are gaining an increasing amount of attention because of their excellent chemical and thermal stabilities, ultra-high Brunauer-Emmett-Teller (BET) surface areas and porosities, as well as the high amount of nitrogen functionalities in their networks. Owing to these remarkable properties, CTFs have been applied in many fields, including catalysis [11-13], gas adsorption and storage [14-16], sorbent materials [17,18], organic semiconductors [19], electrical materials [20,21] and others [22-24].

\footnotetext{
* Corresponding author. Tel: +86-411-84379571; Fax: +86-411-84675584; E-mail: dengwq@dicp.ac.cn This work was supported by the National Natural Science Foundation of China (21373202, 21525315). DOI: 10.1016/S1872-2067(17)62771-2 | http://www.sciencedirect.com/science/journal/18722067 | Chin. J. Catal., Vol. 38, No. 3, March 2017
} 
To synthesize CTFs on a large scale for potential commercialization, an economical synthetic pathway is required. The key monomers used in CTFs are multiple cyano-substituted benzenes, but these are not available on a large scale. The traditional synthetic routes to cyano-substituted benzenes include Rosenmund von Braun reactions [25-27] from aryl halides, diazotization of anilines and the Sandmeyer reaction [28]. However, these synthetic methodologies are associated with the use of overstoichiometric amounts of toxic cyanides, such as $\mathrm{Zn}(\mathrm{CN})_{2}$ [29], CuCN [30], KCN [31], NaCN [32] and trimethylsilyl cyanide (TMSCN) [33], as the cyanide source, which is a serious environmental concern. Recently, nontoxic potassium hexacyanoferrate(II) was introduced as a cyanation agent by Beller's group [34-36]. They demonstrated that aryl halides can react with potassium hexacyanoferrate(II) to give cyano compounds in the presence of catalytic amounts of palladium catalysts and ligands such as 1,5-bis(diphenylphosphino)pentane (dpppe), 1,1'-bis(diphenylphosphino)ferrocene (dppf), triphenylphosphine $\left(\mathrm{PPh}_{3}\right)$, tricyclohexylphosphine $\left(\mathrm{PCy}_{3}\right)$ and 2,2'-bis(diphenylphosphino)diphenyl ether (Bpephos). A drawback of this procedure is the need for expensive ligands, which not only greatly increases the cost of the experiments, but also limits the scale of the reaction. Recently, several triazine-functionalized porous polymers were synthesized using imide-functionalized 1,3,5-triazine frameworks and showed high $\mathrm{CO}_{2}$-adsorption capacities [37,38]. Modak et al. [37] reported a one-pot bottom-up synthetic strategy for the triazine-functionalized porphyrin-based porous organic polymer TPOP-1, which showed a $\mathrm{CO}_{2}$ uptake of up to $6.2 \mathrm{mmol} / \mathrm{g}$ at $3 \times$ $10^{5} \mathrm{~Pa}$ and $0{ }^{\circ} \mathrm{C}$. Gomes et al. [38] reported the synthesis of the polymer TRITER-1 by condensation polymerization of 1,3,5tris-(4-aminophenyl)triazine (TAPT) and terephthaldehyde.

In this work, we have developed a new synthetic pathway for CTFs. First, multiple cyano-substituted aromatics were synthesized using inexpensive and nontoxic $\mathrm{K}_{4}\left[\mathrm{Fe}(\mathrm{CN})_{6}\right] \cdot 3 \mathrm{H}_{2} \mathrm{O}$ as the cyanide source for cyanation of aryl bromides. This reaction was catalyzed by $\mathrm{Pd}(\mathrm{OAc})_{2}$ without addition of other ligands. Second, CTFs were synthesized by polymerization of the multiple cyano-substituted aromatics in molten $\mathrm{ZnCl}_{2}$, which acts as both a catalyst and a solvent at temperatures of 400-600 ${ }^{\circ} \mathrm{C}[10]$. The obtained CTFs exhibited excellent $\mathrm{CO}_{2}$ adsorption properties.

\section{Experimental}

\subsection{Reagents}

All reagents were purchased from Alfa Aesar, J\&K Scientific Ltd., Aladdin Reagent and Sigma Aldrich, and were used without further purification. 1,4-Dicyanobenzene (1b), 2,6-dicyanopyridine (2b) and 1,4-dicyanonaphthalene (3b) were prepared from their corresponding aryl bromides with $\mathrm{K}_{4}\left[\mathrm{Fe}(\mathrm{CN})_{6}\right] \cdot 3 \mathrm{H}_{2} \mathrm{O}$ in the presence of $\mathrm{Pd}(\mathrm{OAc})_{2}$ according to a previously reported method [34,39]. 1b-3b were isolated from the reaction mixtures and characterized by ${ }^{1} \mathrm{H}$ NMR and ${ }^{13} \mathrm{C}$ NMR spectroscopy.

\subsection{Analytical methods}

GC-MS analysis was performed on a GCMS-QP2010SE spectrometer. $n$-Hexadecane was selected as the internal standard for GC-MS after optimization. The NMR spectra $\left({ }^{1} \mathrm{H}, 400 \mathrm{MHz}\right.$; ${ }^{13} \mathrm{C}, 100 \mathrm{MHz}$ ) were recorded on a Bruker Mercury Plus $400-\mathrm{MHz}$ spectrometer. $\mathrm{CDCl}_{3}$ was used as the solvent with tetramethylsilane (TMS) as the internal standard. The synthesis of CTFs was carried out in a muffle burner (TSX1200). The specific surface area of the CTFs was measured on an adsorption instrument (Quantachrome Quadrasorb SI).

\subsection{Typical procedure for palladium acetate-catalyzed cyanation of aryl bromides}

Aryl bromide $(6.0 \mathrm{mmol}), \mathrm{K}_{4}\left[\mathrm{Fe}(\mathrm{CN})_{6}\right] \cdot 3 \mathrm{H}_{2} \mathrm{O}(2.4 \mathrm{mmol})$, $\mathrm{Na}_{2} \mathrm{CO}_{3}(6.0 \mathrm{mmol})$ and $\mathrm{Pd}(\mathrm{OAc})_{2}$ catalyst $(0.2 \mathrm{~mol} \%$ relative to the aryl bromide) were mixed in NMP $(12 \mathrm{~mL})$ in a $25-\mathrm{mL}$ flame-dried double-neck round-bottom flask and heated with stirring at $130{ }^{\circ} \mathrm{C}$ under argon. The progress of the reaction was monitored by GC-MS. At the end of the reaction, the mixture was cooled to room temperature. Samples were quenched with $\mathrm{H}_{2} \mathrm{O}$ (or with sat. $\mathrm{NH}_{4} \mathrm{Cl}$ when pyridines were used as substrates), and extracted with EtOAc $(25 \mathrm{~mL} \times 3)$. The organic layer was washed with water $(15 \mathrm{~mL} \times 3)$ and $5 \% \mathrm{NH}_{3} \cdot \mathrm{H}_{2} \mathrm{O}(15$ $\mathrm{mL} \times 2$ ), and then dried over $\mathrm{Na}_{2} \mathrm{SO}_{4}$. Evaporation of the solvent left the crude product, which was further purified by column chromatography over silica gel (60-120 mesh) eluting with petroleum ether/ethyl acetate to afford the pure aryl nitrile.

1,4-Dicyanobenzene (1b, DCB). ${ }^{1} \mathrm{H}$ NMR ( $\left.\mathrm{CDCl}_{3}, 400 \mathrm{MHz}\right): \delta$ $=7.80(\mathrm{~s}, 4 \mathrm{H}) ;{ }^{13} \mathrm{C}$ NMR $\left(101 \mathrm{MHz}, \mathrm{CDCl}_{3}\right): \delta=132.81,117.00$, 116.76 .

2,6-Dicyanopyridine (2b, DCP). ${ }^{1} \mathrm{H}$ NMR $\left(\mathrm{CDCl}_{3}, 400 \mathrm{MHz}\right): \delta$ $=8.15(\mathrm{dd}, J=8.4,7.4 \mathrm{~Hz}, 1 \mathrm{H}), 7.99$ (d, $J=7.8 \mathrm{~Hz}, 2 \mathrm{H}) ;{ }^{13} \mathrm{C}$ NMR $\left(101 \mathrm{MHz}, \mathrm{CDCl}_{3}\right): \delta=139.13,135.22,131.29,115.53$.

1,4-Dicyanonaphthalene (3b, DCN). ${ }^{1} \mathrm{H}$ NMR $\left(\mathrm{CDCl}_{3}, 400\right.$ MHz): $\delta=8.35$ (dd, $J=6.4,3.2 \mathrm{~Hz}, 2 \mathrm{H}), 7.98(\mathrm{~s}, 2 \mathrm{H}), 7.87$ (dd, $J=$ 6.4, $3.2 \mathrm{~Hz}, 2 \mathrm{H}) ;{ }^{13} \mathrm{C}$ NMR (101 MHz, $\left.\mathrm{CDCl}_{3}\right): \delta=132.00,131.09$, 130.30, 126.03, 116.27, 115.20.

\subsection{Synthetic procedure for CTFS}

Traditional CTF synthesis has been described elsewhere [10]. In this work, aryl nitriles (7.8 mmol) and anhydrous $\mathrm{ZnCl}_{2}$ (39.0 mmol) were transferred into a quartz ampoule $\left(15 \mathrm{~cm}^{3}\right.$ ) under an inert atmosphere. The ampoule was evacuated, sealed and heated to $400{ }^{\circ} \mathrm{C}$ for $20 \mathrm{~h}$ and then to $600{ }^{\circ} \mathrm{C}$ for another 20 $\mathrm{h}$. The ampoule was then cooled to room temperature and opened carefully (Caution: the ampoule is under pressure, which is released on opening). The reaction mixture was then ground and washed thoroughly with large amounts of water to remove most of the $\mathrm{ZnCl}_{2}$. It was then stirred in dilute $\mathrm{HCl}$ for $15 \mathrm{~h}$ to remove the residual salt. After this purification step, the resulting black powder was filtered, washed successively with water and THF and dried in vacuum at $120{ }^{\circ} \mathrm{C}$. The yield of the reaction was high (>91\%) to quantitative. 


\section{Results and discussion}

3.1. $P d(\mathrm{OAc})_{2}$-catalyzed cyanation of 1,4-dibromobenzene with $\mathrm{K}_{4}\left[\mathrm{Fe}(\mathrm{CN})_{6}\right] \cdot 3 \mathrm{H}_{2} \mathrm{O}$

We used 1,4-dibromobenzene as a model substrate to screen suitable reaction conditions for the cyanation of aryl bromides (Table 1). We obtained similar yields using $\mathrm{N}, \mathrm{N}$-dimethylformamide (DMF) and 1-methyl-2-pyrrolidinone (NMP) as the solvent (around 60\%, Table 1, Entries 1 and 3); however, the yield decreased to only $41 \%$ after replacing the solvent with $\mathrm{N}, \mathrm{N}$-dimethylacetamide (DMAc) (Table 1, Entry 2). To our surprise, a high yield of 1,4-dicyanobenzene was obtained at a relatively low catalyst concentration when the reaction time was prolonged (Table 1, Entries 5 and 6). However, increasing the amount of $\mathrm{Pd}(\mathrm{OAc})_{2}$ led to a decrease in the yield (Table 1, Entries 7-9). This might have been caused by excessive catalyst aggregation and transformation to insoluble palladium black $[34,40]$. In practice, the use of $(0.1-0.2) \mathrm{mol} \%$ ligand-free $\mathrm{Pd}(\mathrm{OAc})_{2}$ gives good yields in the cyanation reaction of 1,4-dibromobenzene with $\mathrm{K}_{4}\left[\mathrm{Fe}(\mathrm{CN})_{6}\right] \cdot 3 \mathrm{H}_{2} \mathrm{O}$ (NMP, $\mathrm{Na}_{2} \mathrm{CO}_{3}$, $130{ }^{\circ} \mathrm{C}$ ). No desired product was observed when the cyanation was performed in DMSO, toluene or ethylene glycol owing to the poor solubility of 1,4-dibromobenzene and $\mathrm{K}_{4}\left[\mathrm{Fe}(\mathrm{CN})_{6}\right]$ (Table 1, Entries 10-12). The best reaction conditions were thus determined to be $0.2 \mathrm{~mol} \% \mathrm{Pd}(\mathrm{OAc})_{2}$ and NMP as the solvent, with a reaction time of $2 \mathrm{~h}$ (> 99\%) (Table 1, Entry 4).

\section{2. $P d(\mathrm{OAc})_{2}$-catalyzed cyanation of aryl bromides with $\mathrm{K}_{4}\left[\mathrm{Fe}(\mathrm{CN})_{6}\right] \cdot 3 \mathrm{H}_{2} \mathrm{O}$}

Based on the above result, we extended the substrate scope to heteroaromatic compound 2,6-dibromopyridine (2a) and polycyclic aromatic hydrocarbon 1,4-dibromonaphthalene (3a), and the reactions were performed under the optimized reaction conditions (Table 2). Accordingly, 3a was almost com-

\section{Table 1}

Optimization of the reaction conditions for the cyanation of 1,4-dibromobenzene a.

\begin{tabular}{lccccc} 
Entry & $\begin{array}{c}\mathrm{Pd}(\mathrm{OAc})_{2} \\
(\mathrm{~mol} \%)\end{array}$ & Solvent & $\begin{array}{c}\text { Time } \\
(\mathrm{h})\end{array}$ & $\begin{array}{c}\text { Conv. } \\
(\%)\end{array}$ & $\begin{array}{c}\text { Yield }^{\mathrm{b}} \\
(\%)\end{array}$ \\
\hline 1 & 0.2 & DMF & 2 & 62 & 60 \\
2 & 0.2 & DMAc & 2 & 43 & 41 \\
3 & 0.2 & NMP & 1 & 66 & 63 \\
4 & 0.2 & NMP & 2 & 100 & $>99$ \\
5 & 0.05 & NMP & 4 & 72 & 71 \\
6 & 0.1 & NMP & 4 & 89 & 89 \\
7 & 0.3 & NMP & 4 & 79 & 78 \\
8 & 0.4 & NMP & 4 & 77 & 76 \\
9 & 0.5 & NMP & 4 & 55 & 53 \\
10 & 0.2 & DMSO & 2 & 0 & 0 \\
11 & 0.2 & Toluene & 2 & 0 & 0 \\
12 & 0.2 & Ethylene glycol & 2 & 0 & 0 \\
\hline
\end{tabular}

a Reaction conditions: $6.0 \mathrm{mmol}$ 1,4-dibromobenzene, $2.4 \mathrm{mmol}$ $\mathrm{K}_{4}\left[\mathrm{Fe}(\mathrm{CN})_{6}\right] \cdot 3 \mathrm{H}_{2} \mathrm{O}, 6.0 \mathrm{mmol} \mathrm{Na} 2 \mathrm{CO}_{3}, 12 \mathrm{~mL}$ solvent, $\mathrm{Pd}(\mathrm{OAc})_{2}$, under $\mathrm{Ar}$, $130^{\circ} \mathrm{C}$.

${ }^{\mathrm{b}}$ Determined by GC-MS with $n$-hexadecane as the internal standard.
Table 2

$\operatorname{Pd}(\mathrm{OAc})_{2}$-catalyzed cyanation of various aryl bromides a.

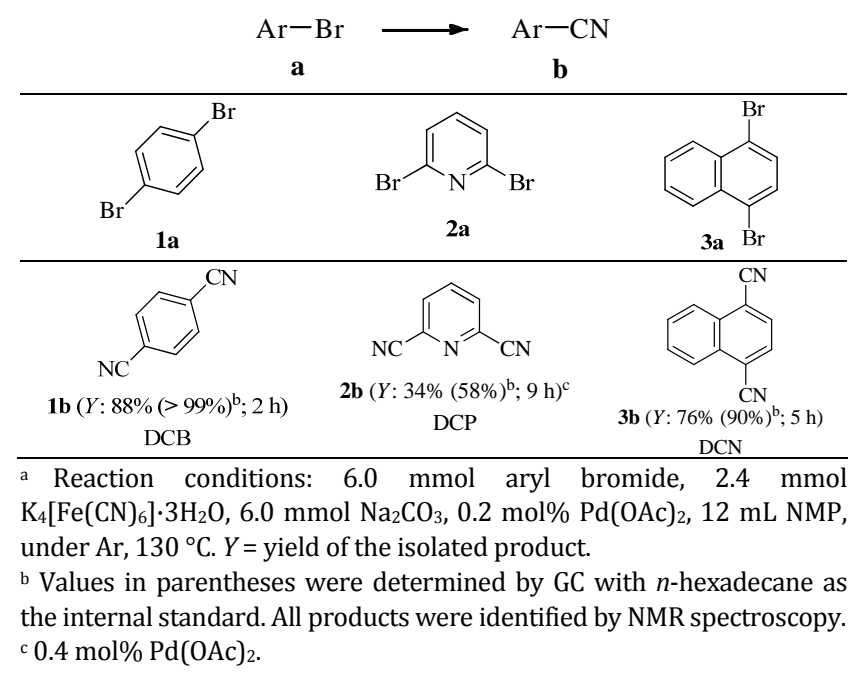

pletely converted to 1,4-dicyanonaphthalene (3b). However, the yield of 2,6-dicyanopyridine (2b) was less than 58\%, even after $9 \mathrm{~h}$ of reaction time.

\section{3. $\quad N_{2}$ adsorption of CTFs}

CTFDCB, CTFDCP [10] and CTFDCN frameworks (Table 2) were synthesized by heating a mixture of the nitrile monomers DCB, DCP and DCN and $\mathrm{ZnCl}_{2}$ in quartz ampules at $400-600{ }^{\circ} \mathrm{C}$ for 40 h. The molten $\mathrm{ZnCl}_{2}$ acts as both solvent and catalyst for the self-polymerization of the triazine rings. The molar ratio of $\mathrm{ZnCl}_{2}$ to the nitrile monomer was 5:1, which allowed the reaction to proceed smoothly.

The porosity, that is, the surface area and pore volume, and the pore size distribution of all CTFs were characterized by $\mathrm{N}_{2}$ adsorption measurements (Fig. 1). All CTFs were outgassed in vacuum at $150{ }^{\circ} \mathrm{C}$ for $10 \mathrm{~h}$, and the results are listed in Table 3 . As shown in Fig. 1(a), the $\mathrm{N}_{2}$ isotherms indicate that the three polymers are microporous; this is also demonstrated by the sharp adsorption/desorption step in the low relative pressure region $\left(P / P_{0}=0-0.05\right)$. The isotherms for $\mathrm{CTF}_{\mathrm{DCB}}$ and $\mathrm{CTF}_{\mathrm{DCN}}$ also exhibit hysteresis loops, which indicate the presence of mesopores. The H2-type hysteresis loops present in the $\mathrm{CTF}_{\mathrm{DCB}}$ and $\mathrm{CTF}_{\mathrm{DCN}}$ desorption isotherms may be caused by the different mechanisms of the condensation and evaporation processes in the micro- and mesopores [41]. The surface areas of the CTFs, calculated using the BET equation, were 2404, 1650 and $780 \mathrm{~m}^{2} / \mathrm{g}$ for $\mathrm{CTF}_{\mathrm{DCB}}, \mathrm{CTF}_{\mathrm{DCP}}$ and $\mathrm{CTF}_{\mathrm{DCN}}$, respectively. The pore size distributions of $\mathrm{CTF}_{\mathrm{DCB}}, \mathrm{CTF}_{\mathrm{DCP}}$ and $\mathrm{CTF}_{\mathrm{DCN}}$ were calculated by HK methods. As shown in Fig. 1(b), all three CTFs exhibit small micropore diameters centered around $0.5 \mathrm{~nm}$; for example, $\mathrm{CTF}_{\mathrm{DCB}}$ had a maximum pore size of $0.57 \mathrm{~nm}$. Moreover, the overall micropore volume of $\mathrm{CTF}_{\mathrm{DCB}}$ was $0.85 \mathrm{~cm}^{3} / \mathrm{g}$, and those of $\mathrm{CTF}_{\mathrm{DCP}}$ and $\mathrm{CTF}_{\mathrm{DCN}}$ were 0.76 and $0.52 \mathrm{~cm}^{3} / \mathrm{g}$, respectively (Table 3). The porosity and texture of the CTFs were homogeneous and the presence of small micropores was confirmed by the high-resolution transmission electron microscopy images shown in Fig. 2. 

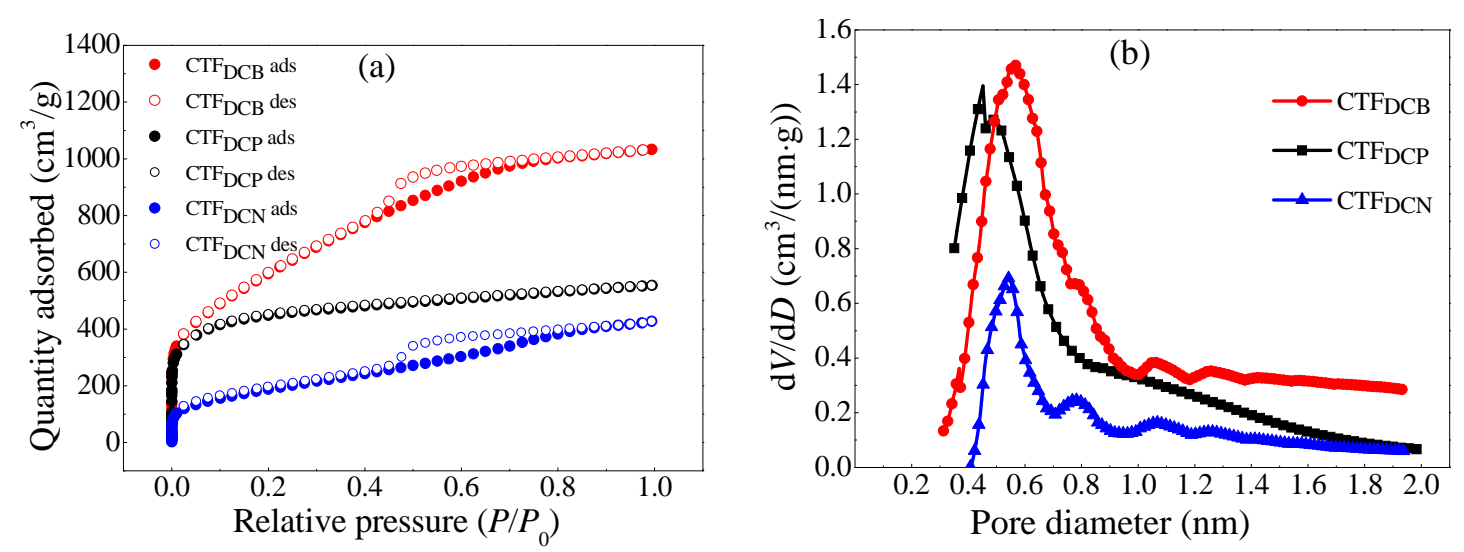

Fig. 1. (a) $\mathrm{N}_{2}$ adsorption isotherms of CTFs at $-196^{\circ} \mathrm{C}$; (b) Pore size distributions of $\mathrm{CTF}_{\mathrm{DCB}}$, $\mathrm{CTF}_{\mathrm{DCP}}$ and $\mathrm{CTF}_{\mathrm{DCN}}$.

Table 3

Porosity data for CTFs from $\mathrm{N}_{2}$ isotherms measured at $-196^{\circ} \mathrm{C}$.

\begin{tabular}{lcccc}
\hline CTFs & Monomer & $\begin{array}{c}\text { Surface area }{ }^{a} \\
\left(\mathrm{~m}^{2} / \mathrm{g}\right)\end{array}$ & $\begin{array}{c}\text { Micropore volume }^{\mathrm{b}} \\
\left(\mathrm{m}^{3} / \mathrm{g}\right)\end{array}$ & $\begin{array}{c}\text { Pore size }^{\mathrm{c}} \\
(\mathrm{nm})\end{array}$ \\
\hline $\mathrm{CTF}_{\mathrm{DCB}}$ & DCB & 2404 & 0.85 & 0.57 \\
$\mathrm{CTF}_{\mathrm{DCP}}$ & DCP & 1650 & 0.76 & 0.45 \\
$\mathrm{CTF}_{\mathrm{DCN}}$ & DCN & 780 & 0.52 & 0.54 \\
\hline
\end{tabular}

a Determined by the BET equation over the relative pressure range described in reference.

b Determined at $P / P_{0}=0.99$.

${ }^{c}$ Determined by nonlocal density functional theory.

\section{4. $\mathrm{CO}_{2}$ adsorption of CTFs}

As shown in Fig. 3(a) and (b), $\mathrm{CO}_{2}$ adsorption by CTFs was also investigated using volumetric methods at 0 and $25^{\circ} \mathrm{C}$. All of the CTFs showed reversible $\mathrm{CO}_{2}$ adsorption isotherms. The $\mathrm{CO}_{2}$ uptake of $\mathrm{CTF}_{\mathrm{DCP}}$, which was synthesized from 2,6-dicyan- opyridine, reached 225 and $154 \mathrm{mg} / \mathrm{g}$ under $1 \times 10^{5} \mathrm{~Pa}$ at 0 and $25^{\circ} \mathrm{C}$, respectively. However, the $\mathrm{CO}_{2}$ uptake of $\mathrm{CTF}_{\mathrm{DCB}}$, which had the highest BET surface area among the three CTFs studied, was only $148 \mathrm{mg} / \mathrm{g}$ at $0{ }^{\circ} \mathrm{C}$ and $99 \mathrm{mg} / \mathrm{g}$ at $25^{\circ} \mathrm{C}$, close to the $129 \mathrm{mg} / \mathrm{g}$ at $0{ }^{\circ} \mathrm{C}$ and $97 \mathrm{mg} / \mathrm{g}$ at $25{ }^{\circ} \mathrm{C}$ measured for $\mathrm{CTF}_{\mathrm{DCN}}$. The high adsorption ability of $\mathrm{CTF}_{\mathrm{DCP}}$, compared with those of $\mathrm{CTF}_{\mathrm{DCB}}$ and $\mathrm{CTF}_{\mathrm{DCN}}$, derives from the extra nitrogen atoms in the structure, which serve as active alkali sites and attract $\mathrm{CO}_{2}$ molecules [42]. Comparison of the $\mathrm{CO}_{2}$ uptake of these CTFs with those of metal organic frameworks (MOFs), conjugated microporous polymers (CMPs) [43] and zeolites [44], as well as those obtained under identical conditions for our previously reported CMPs, Co-CMP and Al-CMP [45], shows that the CTFs have good $\mathrm{CO}_{2}$ capture abilities at both 0 and 25 ${ }^{\circ} \mathrm{C}$ (Table 4). To better understand the adsorption properties, the isosteric heats of adsorption were calculated using a variant of the Clausius Clapeyron equation [46] from fits of the $\mathrm{CO}_{2}$ isotherms at different temperatures. As shown in Fig. 3(c), the
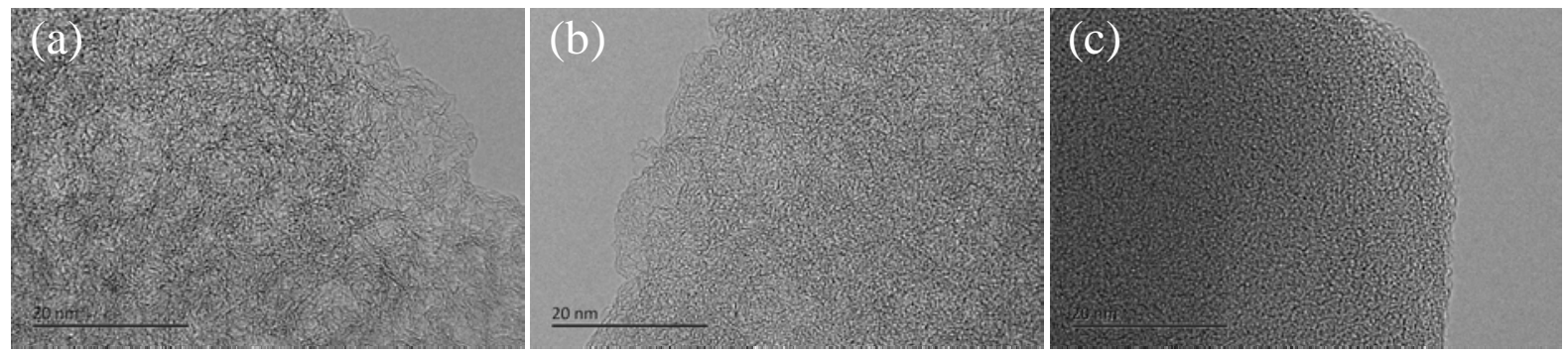

Fig. 2. High-resolution transmission electron micrographs of $\mathrm{CTF}_{D C B}(\mathrm{a}), \mathrm{CTF}_{\mathrm{DCP}}(\mathrm{b})$ and $\mathrm{CTF}_{\mathrm{DCN}}$ (c).
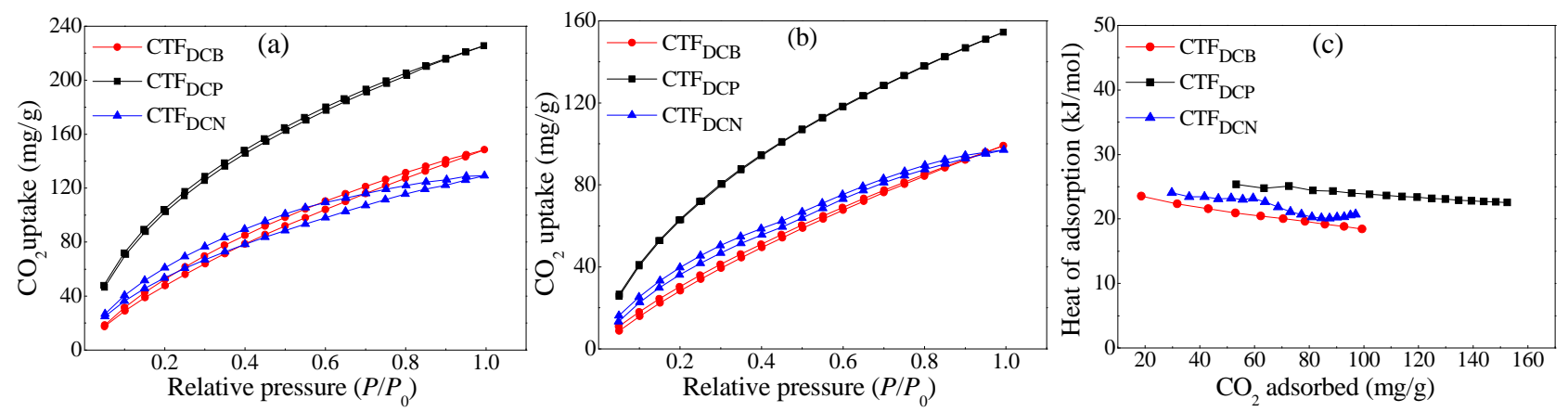

Fig. 3. $\mathrm{CO}_{2}$ adsorption isotherms of $\mathrm{CTFs}$ at $0{ }^{\circ} \mathrm{C}(\mathrm{a})$ and $25^{\circ} \mathrm{C}(\mathrm{b})$, and corresponding heats of adsorption (c). 


\section{Table 4}

Comparison of the $\mathrm{CO}_{2}$ adsorption performance of other common adsorbents measured under $1 \times 10^{5} \mathrm{~Pa}$ at 0 or $25^{\circ} \mathrm{C}$.

\begin{tabular}{lrcc}
\hline \multirow{2}{*}{ Material } & \multirow{2}{*}{$\begin{array}{c}S_{\mathrm{BET}} \\
\left(\mathrm{m}^{2} / \mathrm{g}\right)\end{array}$} & \multicolumn{2}{c}{$\mathrm{CO}_{2}$ uptake $(\mathrm{mg} / \mathrm{g})$} \\
\cline { 3 - 4 } & 2404 & 148 & $\mathrm{At} 25^{\circ} \mathrm{C}$ \\
\hline $\mathrm{CTF}_{\text {DCB }}$ & 1650 & 225 & 99 \\
$\mathrm{CTF}_{\text {DCP }}$ & 780 & 129 & 154 \\
CTF $_{\text {DCN }}$ & 1117 & - & 97 \\
MOF-74 (Mg) & 655 & 272 & 275 \\
SNU-5 & 1400 & - & - \\
HKUST-1 & 760 & 89 & 184 \\
MOP-23 & 4.2 & - & - \\
Si-MCM-41-PEI-50 & 965 & - & 32.9 \\
Co-CMP & 798 & - & 79.3 \\
Al-CMP & & & 76.5 \\
\hline
\end{tabular}

isosteric heats of $\mathrm{CO}_{2}$ adsorption on $\mathrm{CTF}_{\mathrm{DCB}}$, CTFDCN and $\mathrm{CTF}_{\mathrm{DCP}}$ were calculated to be in the range 18.4-23.5, 20.7-24.1 and $22.5-25.3 \mathrm{~kJ} / \mathrm{mol}$, respectively. CTFDCP had the highest isosteric heat of $\mathrm{CO}_{2}$ adsorption, which is consistent with its large $\mathrm{CO}_{2}$-uptake capacity.

\section{Conclusions}

We have developed an environmentally friendly method for the direct synthesis of multiple cyano-substituted aromatic compounds. This method uses palladium acetate without any additional ligands as the catalyst and nontoxic potassium hexacyanoferrate(II) as the cyanide source, thus removing the need for special precautions. Notably, aromatic nitriles could be obtained in excellent yields using catalyst amounts of only (0.2-0.4) mol\%. Moreover, three CTFs were synthesized from the obtained cyano-aromatic compounds. These CTFs exhibited high specific surface areas and excellent $\mathrm{CO}_{2}$ absorption abilities. Furthermore, the synthesized porous polymers had good stability and multiple active sites for metal coordination; we thus expect them to find application in catalyst supports.

\section{References}

[1] C. D. Wood, B. Tan, A. Trewin, H. J. Niu, D. Bradshaw, M. J. Rosseinsky, Y. Z. Khimyak, N. L. Campbell, R. Kirk, E. Stöckel, A. L.
Cooper, Chem. Mater., 2007, 19, 2034-2048.

[2] A. Thomas, Angew. Chem. Int. Ed., 2010, 49, 8328-8344.

[3] D. Zhou, Q. Liu, Q. Y. Cheng, Y. C. Zhao, Y. Cui, T. Wang, B. H. Han, Chin. Sci. Bull., 2012, 57, 3059-3064.

[4] Y. L. Luo, B. Y. Li, W. Wang, K. B. Wu, B. Tan, Adv. Mater., 2012, 24, 5703-5707.

[5] A. P. Côté, A. I. Benin, N. W. Ockwig, M. O'Keeffe, A. J. Matzger, O. M. Yaghi, Science, 2005, 310, 1166-1170.

[6] J. Kuang, L. Q. Liu, Y. Gao, D. Zhou, Z. Chen, B. H. Han, Z. Zhang, Nanoscale, 2013, 5, 12171-12177.

[7] S. Dalapati, M. Addicoat, S. B. Jin, T. Sakurai, J. Gao, H. Xu, S. Irle, S. Seki, D. L. Jiang, Nat. Commun., 2015, 6, 7786

[8] M. J. Bojdys, S. A. Wohlgemuth, A. Thomas, M. Antonietti, Macromolecules, 2010, 43, 6639-6645.

[9] H. Xu, X. Chen, J. Gao, J. B. Lin, M. Addicoat, S. Irle, D. L. Jiang, Chem. Commun., 2014, 50, 1292-1294.

[10] P. Kuhn, M. Antonietti, A. Thomas, Angew. Chem. Int. Ed., 2008, 47, 3450-3453.

[11] X. Y. Wang, Q. Liu, J. X. Jiang, G. J. Jin, H. F. Li, F. N. Gu, G. W. Xu, Z. Y. Zhong, F. B. Su, Catal. Sci. Technol., 2016, 6, 3529-3543.

[12] C. E. Chan-Thaw, A. Villa, P. Katekomol, D. S. Su, A. Thomas, L. Prati, Nano Lett., 2010, 10, 537-541.

[13] K. Kamiya1, R. Kamai, K. Hashimoto, S. J. Nakanishi, Nat. Commun., 2014, 5, 5040.

[14] Y. F. Zhao, K. X. Yao, B. Y. Teng, T. Zhang, Y. Han, Energy Environ. Sci., 2013, 6, 3684-3692.

[15] A. Bhunia, V. Vasylyeva, C. Janiak, Chem. Commun., 2013, 49, 3961-3963.

[16] S. Hug, M. B. Mesch, H. Oh, N. Popp, M. Hirscher, J. Senker, B. V. Lotsch, J. Mater. Chem. A, 2014, 2, 5928-5936.

[17] H. Ren, T. Ben, E. S. Wang, X. F. Jing, M. Xue, B. B. Liu, Y. Cui, S. L. Qiu, G. S. Zhu, Chem. Commun., 2010, 46, 291-293.

[18] A. Bhunia, S. Dey, M. Bous, C. Y. Zhang, W. von Rybinski, C. Janiak, Chem. Commun., 2015, 51, 484-486.

[19] L. M. Tao, F. Niu, D. Zhang, T. M. Wang, Q. H. Wang, New J. Chem., 2014, 38, 2774-2777.

[20] L. Hao, B. Luo, X. L. Li, M. H. Jin, Y. Fang, Z. H. Tang, Y. Y. Jia, M. H. Liang, A. Thomas, J. H. Yang, L. J. Zhi, Energy Environ. Sci., 2012, 5, 9747-9751.

[21] K. Sakaushi, E. Hosono, G. Nickerl, T. Gemming, H. S. Zhou, S. Kaskel, J. Eckert, Nat. Commun., 2013, 4, 1485.

[22] X. Jiang, P. Wang, J. J. Zhao, J. Mater. Chem. A, 2015, 3, 7750-7758.

[23] L. Hao, S. S. Zhang, R. J. Liu, J. Ning, G. J. Zhang, L. J. Zhi, Adv. Mater., 2015, 27, 3190-3195.

\section{Graphical Abstract}

Chin. J. Catal., 2017, 38: 583-588 doi: 10.1016/S1872-2067(17)62771-2

\section{Environmentally benign and economic synthesis of covalent triazine-based} frameworks

Ling Zhang, Xue Liu, Rui-Xia Yang, Nian-Yu Huang, Wei-Qiao Deng *

China Three Gorges University; Dalian Institute of Chemical Physics, Chinese

Academy of Sciences

Covalent triazine-based frameworks were prepared from the corresponding dicyano monomers by cyanation of aryl bromides with nontoxic potassium hexacyanoferrate(II) in the presence of palladium acetate.

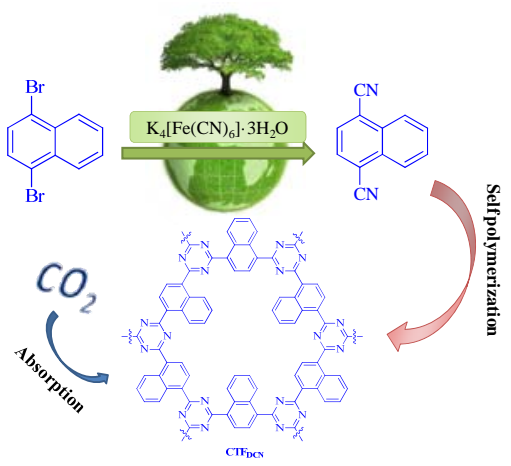


[24] J. L. Liu, Y. J. Hu, J. J. Cao, Catal. Commun., 2015, 66, 91-94.

[25] K. W. Rosenmund, E. Struck, Ber. Dtsch. Chem. Ges., 1919, 52, 1749-1756.

[26] D. T. Mowry, Chem. Rev., 1948, 48, 189-283.

[27] C. Galli, Chem. Rev., 1988, 88, 765-792.

[28] H. H. Hodgson, Chem. Rev., 1947, 40, 251-277.

[29] J. Lindley, Tetrahedron, 1984, 40, 1433-1456.

[30] M. Sundermeier, A. Zapf, M. Beller, J. Sans, Tetrahedron Lett., 2001, 42, 6707-6710.

[31] M. Sundermeier, S. Mutyala, A. Zapf, A. Spannenberg, M. Beller, J. Organomet. Chem., 2003, 684, 50-55.

[32] R. R. Srivastava, S. E. Collibee, Tetrahedron Lett., 2004, 45, 8895-8897.

[33] H. Yu, R. N. Richey, W. D. Miller, J. S. Xu, S. A. May, J. Org. Chem., 2011, 76, 665-668.

[34] T. Schareina, A. Zapf, M. Beller, Chem. Commun., 2004, 12, 1388-1389.

[35] T. Schareina, A. Zapf, M. Beller, J. Organomet. Chem., 2004, 689, 4576-4583.

[36] T. Schareina, R. Jackstell, T. Schulz, A. Zapf, A. Cotté, M. Gotta, M. Beller, Adv. Synth. Catal., 2009, 351, 643-648.
[37] A. Modak, M. Pramanik, S. Inagaki, A. Bhaumik, J. Mater. Chem. A, 2014, 2, 11642-11650.

[38] R. Gomes, P. Bhanja, A. Bhaumik, Chem. Commun., 2015, 51, 10050-10053.

[39] R. Gerber, M. Oberholzer, C. M. Frech, Chem. Eur. J., 2012, 18, 2978-2986.

[40] A. H. M. de Vries, J. M. C. A. Mulders, J. H. M. Mommers, H. J. W. Henderickx, J. G. de Vries, Org. Lett., 2003, 5, 3285-3288.

[41] A. Bhunia, I. Boldog, A. Möller, C. Janiak, J. Mater. Chem. A, 2013, 1 , 14990-14999.

[42] R. Dawson, E. Stockel, J. R. Holst, D. J. Adams, A. I. Cooper, Energy Environ. Sci., 2011, 4, 4239-4245.

[43] K. Sumida, D. L. Rogow, J. A. Mason, T. M. McDonald, E. D. Bloch, Z. R Herm, T. H. Bae, J. R. Long, Chem. Rev., 2012, 112, 724-781.

[44] X. C. Xu, C. S. Song, J. M. Andresen, B. G. Miller, A. W. Scaroni, Microporous Mesoporous Mater., 2003, 62, 29-45.

[45] Y. Xie, T. T. Wang, X. H. Liu, K. Zou, W. Q. Deng, Nat. Commun., 2013, 4, 1960.

[46] X. Zhu, C. C. Tian, S. M. Mahurin, S. H. Chai, C. M. Wang, S. Brown, G. M. Veith, H. M. Luo, H. L. Liu, S. Dai, J. Am. Chem. Soc., 2012, 134, 10478-10484.

\section{一种经济环保地合成共价三嗪骨架的方法}

张 玲 ${ }^{\mathrm{a}, \mathrm{b}}$, 刘 学 ${ }^{\mathrm{b}}$, 杨瑞霞 ${ }^{\mathrm{b}}$, 黄年玉 ${ }^{\mathrm{a}}$, 邓伟侨 ${ }^{\mathrm{b}, *}$

$\mathrm{a}$ 三峡大学生物与制药学院湖北省天然产物研究与开发重点实验室, 湖北宜昌 443002

${ }^{b}$ 中国科学院大连化学物理研究所分子反应动力学国家重点实验室, 辽宁大连116023

摘要: 近年来, 共价有机骨架材料(COFs)由于具有非常好的热化学稳定性、高的孔隙率和比表面积以及可控的表面功能化, 因而在气体存储、分离以及催化等领域拥有潜在的应用价值. 共价三嗪骨架材料(CTFs)是一种特殊的新型共价有机骨架材 料, 它是采用廉价的芳香腈为原料, 在熔融的 $\mathrm{ZnCl}_{2}$ 作用下, 通过离子热聚合反应制成. 本文选择不同的二溴代芳烃化合物, 在无毒的 $\mathrm{K}_{4}\left[\mathrm{Fe}(\mathrm{CN})_{6}\right] \cdot 3 \mathrm{H}_{2} \mathrm{O}$ 和微量 $\mathrm{Pd}(\mathrm{OAc})_{2}$ 的作用下, 通过氰基化反应合成相应的二氰基单体, 二氧基单体再聚合获得共 价三嗪骨架.

澳代芳烃氰基化转化为芳香氧基化合物的反应中, 我们避免使用有毒的金属氰化物, 用廉价无毒的 $\mathrm{K}_{4}\left[\mathrm{Fe}(\mathrm{CN})_{6}\right] \cdot 3 \mathrm{H}_{2} \mathrm{O}$ 来代替, 并不作任何处理直接使用. 同时, 以 $\mathrm{Pd}(\mathrm{OAc})_{2}$ 为催化剂, 不采用任何昂贵的配体, 避免增加实验成本. 我们选择1,4二溴苯为底物, 探索最佳的反应条件, 包括催化剂用量、溶剂以及反应时间, 以得到最高的转化率和产率, 整个反应过程用 GC-MS监测. 然后, 扩展底物有芳香杂环化合物2,6-二溴吡啶和多环芳烃1,4-二溴䒺. 上述三种溴代芳烃氰基化后分别得 到对应的二氰基单体1,4-二氰基苯(DCB), 2,6-二氰基吡啶(DCP)和1,4-二氰基萗(DCN). 二氰基单体再聚合获得共价三嗪骨 架, 依次为 $\mathrm{CTF}_{\mathrm{DCB}}, \mathrm{CTF}_{\mathrm{DCP}}$ 和CTF $\mathrm{DCN}$.

对三种CTF的氮气吸附性能进行了测试, 测得三种聚合物 $\mathrm{CTF}_{\mathrm{DCB}}, \mathrm{CTF}_{\mathrm{DCP}}$ 和CTF $\mathrm{DCN}_{\mathrm{D} N}$ 的BET比表面积依次为2404, 1650 和 $780 \mathrm{~m}^{2} / \mathrm{g}$. 其中, 比表面积最大的 $\mathrm{CTF}_{\mathrm{DCB}}$ 拥有最大的微孔体积 $0.85 \mathrm{~m}^{3} / \mathrm{g}$, 比表面积最小的 $\mathrm{CTF}_{\mathrm{DCN}}$ 的微孔体积也有 0.52 $\mathrm{m}^{3} / \mathrm{g}$. 三种聚合物的孔径分别为 $0.57,0.45$ 和 $0.54 \mathrm{~nm}$. 三种材料的 $\mathrm{CO}_{2}$ 吸附性能测试结果表明, 拥有最高 $\mathrm{N}_{2}$ 吸附量的CTF 在 25 和 $0{ }^{\circ} \mathrm{C}$ 下 $\mathrm{CO}_{2}$ 吸附量分别仅为 148 和 $99 \mathrm{mg} / \mathrm{g}$, 而 $\mathrm{N}_{2}$ 吸附量较小的 $\mathrm{CTF}_{\mathrm{DCP}}$ 的 $\mathrm{CO}_{2}$ 吸附量反而高达 225 和 $154 \mathrm{mg} / \mathrm{g}, \mathrm{CTF} \mathrm{DCN}$ 为 129 和 $97 \mathrm{mg} / \mathrm{g}$. 这表明该类多孔材料的 $\mathrm{CO}_{2}$ 吸附性能不仅与孔体积和比表面积有关, 也与材料中氮原子含量有很大关系. 与其它 $\mathrm{CO}_{2}$ 吸附材料相比, 这三种多孔材料的 $\mathrm{CO}_{2}$ 吸附处于一个较高水平.

关键词: 共价三嗪骨架; 芳基溴化物; 氧基化反应; 六氧合铁(II)酸钾; 醋酸钯

收稿日期: 2016-11-30. 接受日期: 2016-12-25. 出版日期: 2017-03-05.

*通讯联系人. 电话: (0411)84379571; 传真: (0411)84675584; 电子信箱: dengwq@dicp.ac.cn

基金来源: 国家自然科学基金(21373202, 21525315).

本文的英文电子版由Elsevier出版社在ScienceDirect上出版(http://www.sciencedirect.com/science/journal/18722067). 